\title{
Difference of rice farming practices of the Iban in a national boundary area in Borneo and its socio-economic background
}

\author{
Joseph Jawa Kendawang ${ }^{1)}$, Sota Tanaka ${ }^{2) *}$, Ryoji Soda ${ }^{3)}$, Logie Seman ${ }^{1)}$, Mohd Effendi WaSti ${ }^{4)}$ and Katsutoshi Sakurai ${ }^{5)}$ \\ ${ }^{1)}$ Forest Department Sarawak, Wisma Sumber Alam, 93660 Kuching, Sarawak, Malaysia \\ ${ }^{2)}$ Graduate School of Kuroshio Science, Kochi University, B200 Monobe, Nankoku, 783-8502 Japan \\ ${ }^{3)}$ Graduate School of Letters, Hokkaido University, Kita 10, Nishi 7, Kita-ku, Sapporo, 060-0810 Japan \\ ${ }^{4)}$ Graduate School of Agriculture, Kochi University, B200 Monobe, Nankoku, 783-8502 Japan \\ ${ }^{5)}$ Faculty of Agriculture, Kochi University, B200 Monobe, Nankoku, 783-8502 Japan \\ *Corresponding author. Tel: 088-864-5183, Fax: 088-864-5183, E-mail: sotatnk@cc.kochi-u.ac.jp
}

\begin{abstract}
The main purpose of this paper is to clarify the similarities and differences in agricultural practices among the Iban people who live in geographically adjacent areas but different countries, Malaysia and Indonesia. The research areas are Lubok Antu in Sarawak, Malaysia and Lanjak in West Kalimantan, Indonesia. As the Iban people in these areas are of the same ethnicity, their traditional ways of shifting cultivation have been similar. However, at present, the two areas differ considerably in farming area, rice yield and application of fertilizers and agrochemicals. This may be partly due to intensification of agricultural practices and the resulting decline in soil fertility, but is largely due to economic disparities between the two areas. The effects of economic and political factors are analyzed and insights gained by the investigation of additional agricultural and economic activities such as cash crop production, wage-earning jobs and family expenditures in the research areas.
\end{abstract}

Key words: Iban, rice farming practices, shifting cultivation, Lubok Antu, Ulu Kapuas

\section{INTRODUCTION}

The Iban of Sarawak, Malaysia and the Iban residing in neighbouring West Kalimantan, Indonesia belong to the same ethnic group, have the same origins, adopted the same culture, and practice quite similar agricultural activities (rice cultivation). According to Iban oral histories and genealogies, the homeland of the Iban was the Kapuas Basin of West Kalimantan, Indonesia and they were concentrated along the Ketungau tributary prior to their migration into the territory of Sarawak in the middle of the 16th Century (Sandin 1967a, Pringle 1970). Padoch (1982) describes the Iban migratory expansion as a process that was remarkable in scope and rapidity. This is supported by Kedit (1993) who compares the Iban to other ethnic groups in Sarawak, and finds them to be exceptionally mobile, which is a feature of the Iban culture.

A general account of the Iban migration from the time they entered the Batang Lupar and Lubok Antu, Sarawak from the Kapuas Basin, West Kalimantan, Indonesia, until the arrival of James Brooke was described by Sandin (1967b, c) and their movement since the establishment of the Brooke rule was recounted by Pringle (1970). Descriptions of Iban migration and patterns of settlement of specific rivers are found in the works of Freeman (1970, on Balleh region), King (1976, on Leboyan and Embaloh), Sandin (1957, on Niah), and Brooke (1866, on Katibas).

The migration and mobility of the Iban have often been discussed in relation to their agricultural practices, especially those of shifting cultivation. While shifting cultivation has been marked by a long history of academic debate over its ecological sustainability and economic value, Austin (1977) pointed out two points of interest in the present context, namely: 1) the alleged low efficiency of shifting cultivation and 2) the alleged destructiveness of the system. However, based on research done in Sarawak, Hatch \& Lim (1978) argued that while shifting cultivation is a very primitive form of agriculture, it is a viable system and can produce a reasonable yield of upland rice with low inputs if a single cropping of rice is followed by an appropriate duration of fallow. They cautioned, however, that this farming system is very fragile and can be easily broken down under the impact of land and population pressure. In simple terms, the breakdown of the system can be likened to a vicious circle of events that is extremely hard for the shifting cultivators to escape. Land and population pressure may force the farmers to gradually shorten the fallow period, resulting in a decline in rice yield and lowered soil fertility, which they may attempt to compensate for by clearing larger areas for farming (Hatch \& Lim 1978). Ultimately, this will lead to a further decline in rice yield and amplify the risk of soil erosion. However, they can 
compensate for the decline in yields by applying fertilizers or agrochemicals, increasing their reliance on lowland rice cultivation, introducing cash crops, and entering the wage-labor market.

The Iban at Lubok Antu and those residing in Ulu Kapuas in West Kalimantan are in close proximity and both still engage in shifting cultivation. However, an international border splits the two groups into two different countries, Malaysia and Indonesia. The border has also created an artificial division, particularly in terms of agricultural practices and the people's movement as it has exerted significant cultural, political, social and economic influences on the two groups.

Extensive studies of Iban agriculture in Sarawak have been done by Freeman (1955), Jensen (1965), Hatch \& Lim (1978), Padoch (1982), Cramb (1985, 1989), Best (1988) and, most recently, Ichikawa (2000, 2004). In contrast, very limited information is available on Iban agricultural practices in West Kalimantan, besides the studies conducted by Christensen \& Mertz (1993), Lawrence et al. (1998) and Padoch et al. (1998).

The two group's traditional methods of shifting cultivation are similar. However, it is also true that both groups have been altering their ways of agriculture according to their respective political and socio-economic transformations. Furthermore, from the above-mentioned studies, it is difficult to understand how and why the agricultural activities in the two areas have differed. The research sites in Lubok Antu and Lanjak have uplands and lowlands, which are both used for rice farming. Considering that these geographically adjacent areas also have similar climatic features, the differences in agricultural methods and extensive differences in socio-economic status seem to be attributable to the existence of the international border. Analyzing and clarifying the agricultural differences between the two areas from political and socio-economic perspectives will enable one to reconsider the implications of shifting cultivation in the modern context of economic development. Therefore, the objectives of this paper are as follows: (a) to compare the rice farming practices between the Iban at Lubok Antu in Sarawak, Malaysia and those at Lanjak, Ulu Kapuas in West Kalimantan, Indonesia, (b) to evaluate their current economic situation, including various agricultural and non-agricultural activities, and (c) to examine the factors and implications of the differences between the two groups.

\section{STUDY SITES AND METHODS}

This study was conducted in May-June 2004 at Lubok Antu District in Sarawak, Malaysia (01 09' N, $111^{\circ} 52^{\prime}$ E) and in August 2004 at Lanjak, Ulu Kapuas (Kecamatan Batang Lupar) in West Kalimantan Province, Indonesia $\left(01^{\circ} 02^{\prime} \mathrm{N}, 112^{\circ}\right.$ 14' E) (Fig. 1).

The Lubok Antu District is part of the Sri Aman Division in Sarawak, Malaysia with Lubok Antu (town) as the administrative center. It is one of the areas in Sarawak known to have been settled by the Iban in the mid-16th Century. Today, while the Lubok Antu Town Center and other small towns and bazaars have a considerable Chinese population, more than $85 \%$ of the district's population are Iban (1991 census). The area is highly dissected topographically and is drained by the Batang Ai River and its tributaries. Primary forest along the lower reaches of the Batang Ai River has almost totally disappeared due to shifting cultivation, agri-conversion, and past logging. Only the extreme headwaters, gazetted as a National Park in 1991, still have primary forest. The district consists of a mosaic of secondary forest of various ages, upland and lowland (mostly swamp) rice fields, rubber and pepper gardens and oil palm plantations. The population density is still comparatively low (approximately nine people $\mathrm{km}^{-2}$ ).

Lanjak in Ulu Kapuas is a part of the province of West Kalimantan, Indonesia, which borders Sarawak. The Indonesian Government divides provinces into regencies (kabupaten), which are then divided into smaller districts called kecamatan. The Iban live primarily within the Kapuas Hulu Regency and are the predominant population in the four kecamatan along the international border with Sarawak (Kecamatan Nanga Kantuk, Kecamatan Nanga Badau, Kecamatan Batang Lupar and Kecamatan Embaloh Hulu). The incorporation of Iban communities under the early Indonesian governmental bureaucracy maintained the integrity of the longhouse ${ }^{1}$ as a village unit. It is estimated that the Iban population in West Kalimantan is close to 13,000, out of which 2,898 people (444 households) ${ }^{2}$ are in Kecamatan Batang Lupar, where this study was conducted (Tun Jugah Foundation, 2001). This area is now accessible by the 'Northern Road' that was constructed in 1990 and paved in 1995. The road begins at Putussibau and continues for approximately $265 \mathrm{~km}$ through Lanjak and Nanga Badau, near Lubok Antu, to Merakai (Wadley 1998). However, the road condition is poor due to inadequate maintenance and unsatisfactory drainage, making it subject to erosion and landslides during heavy rain. In addition, there is heavy traffic transporting sawn timber through Nanga Badau (the border town 


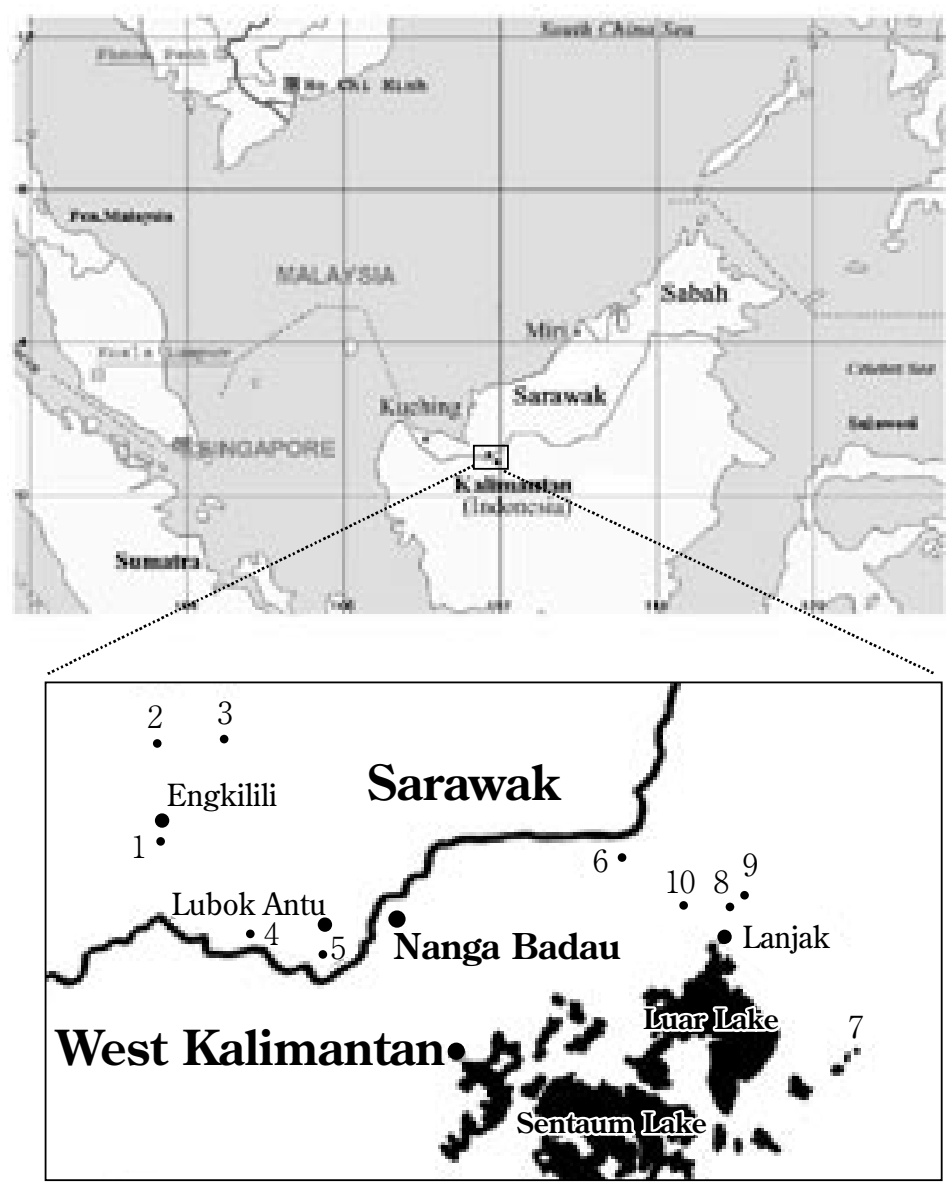

\begin{tabular}{|c|l|}
\hline \multicolumn{2}{|l|}{ Lubok Antu, Sarawak } \\
\hline 1 & Rumah Philip Renggie, Bukong \\
\hline 2 & Rumah Karak ak Nangkai, Stengin \\
\hline 3 & Rumah Bak ak Baring, Sibliau \\
\hline 4 & Rumah Serau Agang, Ng. San Sebor \\
\hline 5 & Rumah Nesau ak Bundol, Panjai Ruai Atas \\
\hline Lanjak, West Kalimantan \\
\hline 6 & Rumah Dayong ak Angkin, Kapar \\
\hline 7 & Rumah Sawing ak Ngindang, Meliau \\
\hline 8 & Rumah Sageng ak Abit, Sg. Sede \\
\hline 9 & Rumah Minsut ak Muling, Kpg. Sawah, Sg. Beso \\
\hline 10 & Rumah Daud ak Runggah, Sg. Sumpa \\
\hline
\end{tabular}

Fig. 1. Location of longhouses in study areas

on the Kalimantan side) to the border town of Lubok Antu in Sarawak. The main agricultural activity in this district is rice planting. For cash, some farmers plant pepper, tap rubber, fish and cut timber in the adjacent forest areas to sell to buyers in Lubok Antu.

Lubok Antu in Sarawak and Nanga Badau in West Kalimantan are linked by an unpaved road and function as transit centers for traffic crossing the international border. Local residents of Sarawak and West Kalimantan can cross the border without any documents to meet the needs of daily life.

At Lubok Antu, five Iban longhouses were visited and 14 out of a total of 135 bilek-families were selected to interview about their socio-economic situation. Similarly, in Lanjak, another five Iban longhouses with a total of 110 families were visited and 10 people, including five village heads, were interviewed ${ }^{3}$. Interviews were conducted using carefully structured questionnaires. Interviewees were asked about their agricultural methods, including shifting cultivation, cash crop cultivation, livestock breeding and fishing. They were also questioned regarding their economic status (e.g. family income and expenditure). Other than the heads of longhouses in Lanjak, respondents could only be asked questions on their rice cultivation, because of time limitations. Rice yield was estimated by recording the number of used $50 \mathrm{~kg}$ fertilizer bags in which they usually kept rice before milling. Then, the yield of the brown rice (dry and unhusked rice) was calculated using the average weight of the bags obtained from a number of measurements. Other Figures, such as the area planted with rice, fallow period, and income and expenditure, were also obtained through our careful interviews with the respondents. Additional information on the general socio-economic situation of each village was mainly garnered from open-ended interviews with the heads of longhouses. 
Table 1. Longhouses surveyed at Lubok Antu, Sarawak (Data were collected in MayJune 2004)

\begin{tabular}{lcrrrr}
\hline & $\begin{array}{c}\text { No. of } \\
\text { bilek- } \\
\text { Namilies }\end{array}$ & \multicolumn{3}{c}{ Population (No. of people) } \\
\hline Rumah Philip Renggie, Bukong & 12 & 48 & 32 & 80 & 6.7 \\
Rumah Kerak ak Nangkai, Stengin & 40 & 96 & 144 & 240 & 6.0 \\
Rumah Bak ak Baring, Sibliau & 45 & 112 & 168 & 280 & 6.2 \\
Rumah Serau Agang, Ng. San Sebor & 10 & 66 & 44 & 110 & 11.0 \\
Rumah Nesau ak Bundol, Panjai Ruai Atas & 28 & 92 & 118 & 210 & 7.5 \\
Total of 5 longhouses & 135 & 414 & 506 & 920 & 6.8 \\
\hline
\end{tabular}

Table 2. Longhouses surveyed at Lanjak, West Kalimantan (Data were collected in August 2004)

\begin{tabular}{lcccccc}
\hline & $\begin{array}{c}\text { No. of } \\
\text { bilek- } \\
\text { families }\end{array}$ & \multicolumn{5}{c}{ Population (No. of people) } \\
\hline Rumah of Longhouse/Locality & 27 & 89 & 73 & 162 & 6.0 \\
Rumah Sawing ak Ngindang, Meliau & 32 & 65 & 64 & 129 & 4.0 \\
Rumah Sageng ak Abit, Sg. Sede & 22 & 44 & 43 & 87 & 4.0 \\
Rumah Minsut ak Muling, Kpg. Sawah, Sg. Beso & 15 & 41 & 33 & 74 & 5.0 \\
Rumah Daud ak Runggah, Sg. Sumpa & 14 & 48 & 38 & 86 & 6.1 \\
Total of 5 longhouses & 110 & 287 & 251 & 538 & 4.9 \\
\hline
\end{tabular}

\section{RESULTS AND DISCUSSION}

\section{Rice Cultivation}

\section{Farming calendar}

The most important agricultural activity carried out by both the Iban in Lubok Antu and those in Lanjak is rice cultivation. There are two types: upland rice cultivation and lowland rice cultivation. The upland rice varieties are planted on hillsides as part of the system of shifting cultivation. Upland rice varieties, as well as lowland varieties, are sometimes planted on low-lying land, depending on the topographical features and rainfall during the planting season. Most of the rice crop is for the farmers' own consumption.

Shifting cultivation of upland rice is conducted mainly in secondary forest areas in both Lubok Antu and Lanjak. The farming calendar for upland rice in Lubok Antu commences in the middle of June (Fig. 2) whereas the Iban in Lanjak normally start their farming season in early May (Fig. 3). As the two neighbouring areas differ little in seasonal climate changes, the difference in the month at which the farming cycle starts is probably due to differences in the date of the harvest festival (Gawai). Iban people traditionally start farming after celebrating the Gawai. While the Iban in West Kalimantan can adjust their agricultural schedule to meet their needs, the Iban in Sarawak start their farming cycle on June 1st, the date officially fixed by the Sarawak Government for the Gawai festival.

For lowland rice cultivation, the farming calendars of the two regions differ depending on whether or not clearing (slashing and sometimes felling) and burning are conducted (Figs. 4 and 5). In Lubok Antu, usually no burning is required, since the farmers use the land every year, applying herbicide to eradicate herbaceous species and other vegetation before transplanting the rice seedling. Lowland rice is planted in swampy land (tanah paya). Rice seeds 


\begin{tabular}{|c|c|c|c|c|c|c|c|c|c|c|c|c|}
\hline & Apr & May & Jun & Jul & Aug & Sept & Oct & Nov & Dec & Jan & Feb & Mar \\
\hline Site Selection & & & & & & & & & & & & \\
\hline Slashing & & & & & & & & & & & & \\
\hline Felling & & & & & & & & & & & & \\
\hline Burning & & & & & & & & & & & & \\
\hline Sowing & & & & & & & & & & & & \\
\hline Weeding & & & & & & & & & & & & \\
\hline Harvesting & & & & & & & & & & & & \\
\hline
\end{tabular}

Fig. 2. Farming calendar for upland rice cultivation at Lubok Antu, Sarawak

\begin{tabular}{|c|c|c|c|c|c|c|c|c|c|c|c|c|}
\hline & Apr & May & Jun & Jul & Aug & Sept & Oct & Nov & Dec & Jan & Feb & Mar \\
\hline Site Selection & & & & & & & & & & & & \\
\hline Slashing & & & & & & & & & & & & \\
\hline Felling & & & & & & & & & & & & \\
\hline Burning & & & & & & & & & & & & \\
\hline Sowing & & & & & & & & & & & & \\
\hline Weeding & & & & & & & & & & & & \\
\hline Harvesting & & & & & & & & & & & & \\
\hline
\end{tabular}

Fig. 3. Farming calendar for upland rice cultivation at Lanjak, West Kalimantan

\begin{tabular}{|c|c|c|c|c|c|c|c|c|c|c|c|c|}
\hline & Apr & May & Jun & Jul & Aug & Sept & Oct & Nov & Dec & Jan & Feb & Mar \\
\hline Sowing & & & & & & & & & & & & \\
\hline Transplanting & & & & & & & & & & & & \\
\hline Weeding & & & & & & & & & & & & \\
\hline Harvesting & & & & & & & & & & & & \\
\hline
\end{tabular}

Fig. 4. Agricultural calendar for lowland rice cultivation at Lubok Antu, Sarawak

\begin{tabular}{|c|c|c|c|c|c|c|c|c|c|c|c|c|}
\hline & Apr & May & Jun & Jul & Aug & Sept & Oct & Nov & Dec & Jan & Feb & Mar \\
\hline Clearing & & & & & & & & & & & & \\
\hline Burning & & & & & & & & & & & & \\
\hline Sowing & & & & & & & & & & & & \\
\hline Transplanting & & & & & & & & & & & & \\
\hline Weeding & & & & & & & & & & & & \\
\hline Harvesting & & & & & & & & & & & & \\
\hline
\end{tabular}

Fig. 5. Agricultural calendar for lowland rice cultivation at Lanjak, West Kalimantan

are sown and seedlings transplanted in September/October, to coincide with the onset of the rainy season. In Lanjak the farmland consists of flat, low-lying areas, both dry and swampy, mostly near river-banks. In the swamp the land is sometimes used for years without a fallow period. The dry land is kept fallow for two to eight years before another rice crop is cultivated. Clearing of small trees and shrubs is done sometime between the end of May to July. Burning is done in August.

Both groups of Iban were observed to continue to practice their traditions and customs with regard to farming. These include the rites of manggul, which marks the inauguration of the farming year (Freeman 1955). The commencement of the Iban agricultural year is also signalled by the dawn rising of the star, Pleiades. For the purpose of rice cultivation, three main constellations are looked for:

(a) Bintang Banyak: Pleiades, which marks the commencement of land selection (manggul).

(b) Bintang Tiga: Orion, which marks the season for dibbling (nugal), i.e. sowing of the rice seed (August/September).

(c) Bintang Tangkong Peredah: Sirius, which marks the end of the growing season. Rice plants sown after Sirius has passed its zenith (about 19 October) will not mature properly. 
Table 3. Rice cultivation in Lubok Antu, Sarawak

\begin{tabular}{lcccc|cc}
\hline Longhouse & Respondent & \multicolumn{3}{c|}{ Upland rice } & \multicolumn{2}{c}{ Lowland rice } \\
\cline { 2 - 7 } & & $\begin{array}{c}\text { Cultivation/ } \\
\text { Fallow (y) }\end{array}$ & $\begin{array}{c}\text { Area } \\
\left(\text { ha family }^{-1}\right)\end{array}$ & $\begin{array}{c}\text { Yield } \\
\left(\mathrm{kg} \mathrm{ha}^{-1}\right)\end{array}$ & $\begin{array}{c}\text { Area } \\
\left(\text { ha family }^{-1}\right)\end{array}$ & $\begin{array}{c}\text { Yield } \\
\left(\mathrm{kg} \mathrm{ha}^{-1}\right)\end{array}$ \\
\hline Rumah Philip & S1 & $1 / 5$ & 2.8 & 410 & 1.2 & 1,340 \\
Rumah Philip & S2 & $1 / 2$ & 1.2 & 960 & 1.2 & 370 \\
Rumah Philip & S3 & No fallow & 0.4 & 450 & 1.2 & 1,040 \\
Rumah Karak & S4 & $1 / 3$ & 2.2 & 450 & 1.2 & 520 \\
Rumah Karak & S5 & $3 / 3$ & 2.6 & 570 & 1.2 & 670 \\
Rumah Karak & S6 & $2 / 2$ & 1.6 & 780 & 1.2 & 670 \\
Rumah Bak & S7 & $1 / 10$ & 1.6 & 610 & 1.6 & 1,950 \\
Rumah Bak & S8 & $1 / 7-8$ & 1.4 & 760 & 0.8 & 1,560 \\
Rumah Bak & S9 & $2 / 2$ & 2.2 & 690 & Nil** & Nil * \\
Rumah Serau & S10 & $1 / 7$ & 1.6 & 950 & 1.6 & 1,110 \\
Rumah Serau & S11 & $2 / 5-7$ & 1.2 & 790 & 0.8 & 1,000 \\
Rumah Serau & S12 & $3 / 3$ & 1.2 & 960 & 0.8 & 560 \\
Rumah Nesau & S13 & No fallow & 1.2 & 590 & 1.6 & 890 \\
Rumah Nesau & S14 & $3 / 4$ & 2.4 & 820 & 0.8 & 1,110 \\
\hline Average & & $2 / 5$ & 1.7 & 699 & 1.2 & 984 \\
\hline
\end{tabular}

* Cultivation for more than 5 years.

**This family did not cultivate lowland rice and the data were omitted from the calculation of averages.

Table 4. Rice cultivation in Lanjak, West Kalimantan

\begin{tabular}{|c|c|c|c|c|c|c|}
\hline \multirow[t]{2}{*}{ Longhouse } & \multirow[t]{2}{*}{ Respondent } & \multicolumn{3}{|c|}{ Upland rice } & \multicolumn{2}{|c|}{ Lowland rice ${ }^{* *}$} \\
\hline & & $\begin{array}{c}\text { Cultivation/ } \\
\text { Fallow (y) }\end{array}$ & $\begin{array}{c}\text { Area } \\
\text { (ha family }^{-1} \text { ) }\end{array}$ & $\begin{array}{l}\text { Yield } \\
\left(\mathrm{kg} \mathrm{ha}^{-1}\right)\end{array}$ & $\begin{array}{c}\text { Area } \\
\left(\text { ha family }^{-1}\right)\end{array}$ & $\begin{array}{c}\text { Yield } \\
\left(\mathrm{kg} \mathrm{ha}^{-1}\right)\end{array}$ \\
\hline Rumah Dayong & $\mathrm{K} 1$ & $1 / 8$ & 0.4 & 1,760 & 0.4 & 1,540 \\
\hline Rumah Dayong & $\mathrm{K} 2$ & $1 / 6$ & 0.8 & 830 & 0.6 & 1,170 \\
\hline Rumah Sawing & K3 & $\mathrm{Nil}^{*}$ & $\mathrm{Nil}^{*}$ & $\mathrm{Nil}^{*}$ & 0.8 & 1,100 \\
\hline Rumah Sawing & $\mathrm{K} 4$ & $\mathrm{Nil}^{*}$ & $\mathrm{Nil}^{*}$ & $\mathrm{Nil}^{*}$ & 0.8 & 1,110 \\
\hline Rumah Sageng & K5 & $1 / 6$ & 0.1 & 1,760 & 0.8 & 1,760 \\
\hline Rumah Sageng & K6 & $1 / 6$ & 2.0 & 710 & 0.8 & 2,230 \\
\hline Rumah Minsut & $\mathrm{K} 7$ & $1 / 6$ & 0.4 & 530 & 0.8 & 1,430 \\
\hline Rumah Minsut & K8 & $1 / 6$ & 1.6 & 670 & 3.2 & 1,280 \\
\hline Rumah Daud & K9 & $1 / 5$ & 0.4 & 330 & 0.8 & 990 \\
\hline Rumah Daud & $\mathrm{K} 10$ & $1 / 5$ & 0.8 & 560 & 1.2 & 1,190 \\
\hline Average & & $1 / 6$ & 0.8 & 893 & 1.0 & 1,380 \\
\hline
\end{tabular}

* These families did not cultivate upland rice and the data were omitted from the calculation of averages.

* * Farmers occasionally left their land fallow for 2 to 8 years. 
The older Iban generation has a profound knowledge of the significance of stars (bintang) to guide them in their farming calendar, but in Lubok Antu this knowledge is gradually disappearing, particularly among the younger generation.

\section{Method of rice cultivation and rice yield}

Tables 3 and 4 show the methods of rice cultivation and the rice yield obtained in Lubok Antu and Lanjak, respectively.

Padoch (1982) reported that a single rice crop was followed by a fallow period ranging from four to 15 years or more in shifting cultivation at a long-settled area, Nanga Jela (one of the tributaries of the Batang Ai River and over $10 \mathrm{~km}$ away from Lubok Antu). In the study reported here, the Iban in Lubok Antu occasionally shorten the duration of fallow to less than three years and prolong cultivation to two years or more. Even a no-fallow system (continuous cultivation for more than five years) was observed. On the other hand, the duration of cultivation and fallow in Lanjak is fairly uniform and within the range reported by Padoch. For lowland rice cultivation, as mentioned above, all the dry land and some of the swampy land in Lanjak are kept fallow for two to eight years, while no fallow system is used in Lubok Antu.

These differences can be ascribed to the shortage of manpower available for rice cultivation, as well as a shortage of land. According to some respondents in Lubok Antu, farmland accessibility is one of the important factors in site selection for shifting cultivation. Since male member(s) of a family often engage(s) in off-farm work for wages, carrying out physically heavy tasks, such as felling trees or carrying rice to the longhouse, can be a serious problem for the family. Therefore, families tend to select land near the longhouse. People in Lubok Antu also acknowledge that the land available for rice farming has decreased, since the land use in the village has become more diversified with the introduction of various cash crops such as pepper, rubber and oil palm. These tendencies lead to intensive land use (both upland and lowland) in Lubok Antu. It should be noted that trees are often felled with a chainsaw in Lubok Antu, even in young secondary forests, but mainly with an axe in Lanjak.

It was observed that the amounts of chemical fertilizers, herbicide and insecticide being used by the Iban farmers in Lanjak are quite small compared to that being used in Lubok Antu. In Lubok Antu, all of the families interviewed use the chemical fertilizer 'Urea' although they preferred 'NPK' (NPK as major elements with other trace elements). This can be ascribed to the price of Urea (RM 442 for a $50 \mathrm{~kg}$ bag), which is cheaper than that of NPK (RM $53 \mathrm{for} 50 \mathrm{~kg}$ bag). The Department of Agriculture gives assistance to each family to buy one $25 \mathrm{~kg}$ bag of Urea at RM5 for rice cultivation. Although the annual application rate of Urea or NPK does not exceed $100 \mathrm{~kg} \mathrm{ha}^{-1}$ for upland nor for lowland areas, the actual amount applied depends largely on the financial ability of the family. In Lanjak, on the other hand, only three out of ten families use fertilizers. In most cases they apply one $50 \mathrm{~kg}$ bag of either Urea or NPK for upland and/or lowland rice cultivation, corresponding to an average rate of $74 \mathrm{~kg} \mathrm{ha}^{-1}$. Other families in Lanjak never use chemical fertilizers. Herbicide is popularly used both in Lubok Antu and Lanjak. The major brand is 'Gramoxone', which costs RM 32 to RM 43 per gallon at Lubok Antu and RM 58 at Lanjak. The application rate for upland and lowland rice cultivation is 3.2 and 2.9 gallon ha $\mathrm{ha}^{-1}$ in Lubok Antu and 1.5 and 3.2 gallon ha $^{-1}$ in Lanjak, respectively. In contrast, insecticide (mostly Malathion, RM16 per liter) is used only in Lubok Antu, and at a rate of approximately $5 \mathrm{~L} \mathrm{ha}^{-1}$ both for upland and lowland rice. The difference in the application of the chemical fertilizers and agrochemicals can be attributed partly to the financial status of the farmers and the price difference between Lubok Antu and Lanjak. We observed that the Iban in Lanjak who can afford to go frequently across the border to Lubok Antu are likely to buy herbicides at Lubok Antu to bring back to their farmland in Lanjak. However, they hesitate to buy fertilizers, because an extra fee is charged for loading and transporting fertilizers to Lanjak. Agricultural extension programs by the Department of Agriculture in Sarawak, which aim to encourage shifting cultivators to practice a sedentary form of farming, may also contribute to the differences. When fertilizers and agrochemicals are used in Lanjak, only the application rate of herbicide is nearly equivalent to that in Lubok Antu, indicating the preferential use of herbicide for rice production. During the interview, some respondents replied that the use of herbicide reduces the heavy task of weeding during rice cultivation.

The average planting area per family is 2.9 ha (1.7 ha for upland and 1.2 ha for lowland rice cultivation) in Lubok Antu and 1.8 ha ( 0.8 ha for upland and 1.0 ha for lowland rice cultivation) in Lanjak. This shows that the farm size per family in Lubok Antu is 1.6 times bigger than that in Lanjak. Similarly, the farm size per person is also bigger in Lubok Antu (0.35 ha in Lubok Antu and 0.29 ha in Lanjak). On the other hand, rice yield for Lubok Antu (699 $\mathrm{kg} \mathrm{ha}^{-1}$ for upland and $984 \mathrm{~kg} \mathrm{ha}^{-1}$ for lowland) is lower than that in Lanjak (893 kg ha-1 for upland and 1,380 kg ha $\mathrm{kgr}^{-1}$ lowland). According to Hatch \& Lim (1978), shifting cultivators tend to clear a bigger area for farming to compensate for the reduction in 
yield. In terms of rice yield per person, the yield corresponded to $200 \mathrm{~kg} \mathrm{ha}^{-1}$ in Lubok Antu and $367 \mathrm{~kg} \mathrm{ha}^{-1}$ in Lanjak.

These results indicate that, in terms of rice yield both per area and per person, Lubok Antu has lower rice productivity than Lanjak, even with extensive use of fertilizers and agrochemicals. However, as described later, those in Lubok Antu supplement their livelihood with cash income from non-agricultural activities.

Intensive land use may lead to a decline in soil fertility under the humid tropical climate of Borneo. Even in traditional shifting cultivation with a one year cropping period, it is reported that the positive effects of burning, that is, the soil-fertilizing effects of ash addition, disappear rapidly and, in some cases, the soil fertility even deteriorates compared to that before burning, due to nutrient loss by erosion and leaching (Kendawang et al. 2004, Tanaka et al . 2004). Unless an adequate fallow period is allowed, soil fertility is not restored (Szott et al. 1999). Although fertilizer and agrochemical application is indispensable under such intensive land use, it is suggested from the data from Lubok Antu that the application of agrochemicals can compensate for only some of the decline in soil fertility and rice yield.

\section{Other agricultural activities}

\section{Planting of cash crops}

The Iban at both Lubok Antu and Lanjak plant cash crops such as rubber, pepper and cocoa in varying amounts. Pepper (Piper nigrum) was first introduced in Lubok Antu in the late 1930s and has been the major source of cash income for the people in the area for many years. On the other hand, in Lanjak, pepper planting was introduced in the 1970s to a longhouse and in the 1990s to the other four longhouses. According to the village heads interviewed, $81 \%$ of Lubok Antu families (110 out of 135 families) and $70 \%$ of Lanjak families (77 out of 110 families) have a pepper garden. All of the families interviewed, both in Lubok Antu and Lanjak, usually sell black pepper in Lubok Antu. The market price

Table 5. Major monthly income and expenditures in Lubok Antu, Sarawak (RM/m)

\begin{tabular}{|c|c|c|c|c|c|c|c|c|c|c|c|c|c|c|c|}
\hline \multirow[t]{2}{*}{ Longhouse } & \multirow[t]{2}{*}{ Respondent } & \multicolumn{8}{|c|}{ Income } & \multicolumn{6}{|c|}{ Expenditure } \\
\hline & & Pepper & Rubber & Rice & Vegetables & Timber & $\begin{array}{c}\text { Oil } \\
\text { Palm }\end{array}$ & $\begin{array}{l}\text { Wages } \\
\text { earned }\end{array}$ & Total & Food & Fuel & Electricity & Gas & Education & Total \\
\hline Rumah Philip & $\mathrm{S} 1$ & 180 & 500 & Nil & 100 & Nil & Nil & Nil & 780 & 400 & 80 & 12 & ND & 100 & 592 \\
\hline Rumah Philip & S2 & 200 & 350 & Nil & 60 & Nil & Nil & Nil & 610 & 300 & 30 & Nil & ND & 150 & 480 \\
\hline Rumah Philip & S3 & Nil & 200 & Nil & 30 & Nil & Nil & 500 & 730 & 350 & 30 & Nil & ND & 30 & 410 \\
\hline Rumah Karak & S4 & 250 & 500 & 30 & ND & Nil & 360 & Nil & 1,140 & 150 & 20 & Nil & ND & 100 & 270 \\
\hline Rumah Karak & S5 & Nil & 100 & 30 & Nil & Nil & 360 & 600 & 1,090 & 400 & 0 & Nil & ND & 300 & 700 \\
\hline Rumah Karak & S6 & Nil & 1000 & 250 & Nil & Nil & 360 & Nil & 1,610 & 250 & 40 & Nil & ND & 100 & 390 \\
\hline Rumah Bak & S7 & 150 & Nil & Nil & 100 & Nil & 250 & $1,500^{* *}$ & 2,000 & 1,000 & 500 & 30 & ND & 100 & 1,630 \\
\hline Rumah Bak & S8 & Nil & 250 & Nil & Nil & Nil & 250 & Nil & 500 & 200 & 35 & 20 & ND & Nil & 255 \\
\hline Rumah Bak & S9 & 70 & 600 & Nil & Nil & Nil & 250 & 1,500 & 2,420 & 300 & 150 & 25 & ND & Nil & 475 \\
\hline Rumah Serau & $\mathrm{S} 10$ & 200 & 500 & Nil & 100 & Nil & Nil & Nil & 800 & 500 & 200 & 35 & ND & 150 & 885 \\
\hline Rumah Serau & S11 & 150 & Nil & Nil & 50 & Nil & Nil & Nil & 200 & 100 & 0 & 25 & ND & 30 & 155 \\
\hline Rumah Serau & $\mathrm{S} 12$ & 500 & Nil & Nil & 50 & Nil & Nil & Nil & 550 & 150 & 0 & 25 & ND & 30 & 205 \\
\hline Rumah Nesau & $\mathrm{S} 13$ & 200 & Nil & Nil & Nil & Nil & 500 & Nil & 700 & 300 & 30 & 15 & ND & Nil & 345 \\
\hline Rumah Nesau & S14 & 300 & 400 & Nil & 100 & Nil & 500 & $3,000^{* *}$ & 4,300 & 250 & 200 & 30 & ND & 100 & 580 \\
\hline Average & & 220 & 440 & 103 & 74 & Nil & 354 & 1,420 & 1,245 & 332 & 94 & 24 & ND & 108 & 527 \\
\hline
\end{tabular}

Nil : No income from the product (the data were omitted from the calculation of averages).

ND: no data available.

* Figures in brackets indicate the number of family members who work outside the village and make remittances.

** Income from transporting harvested oil palm fruits from plantation to a mill. 
Table 6. Major monthly income and expenditures in Lanjak, West Kalimantan (RM/m)

\begin{tabular}{|c|c|c|c|c|c|c|c|c|c|c|c|c|c|c|c|}
\hline \multirow[t]{2}{*}{ Longhouse } & \multirow[t]{2}{*}{ Respondent } & \multicolumn{8}{|c|}{ Income } & \multicolumn{6}{|c|}{ Expenditure } \\
\hline & & Pepper & Rubber & Rice & Vegetables & Timber & $\begin{array}{c}\text { Oil } \\
\text { Palm }\end{array}$ & $\begin{array}{l}\text { Wages } \\
\text { earned }\end{array}$ & Total & Food & Fuel & Electricity & Gas & Education & Total \\
\hline Rumah Dayong & $\mathrm{K} 1$ & 90 & 100 & Nil & ND & 200 & Nil & Nil & 390 & 150 & 30 & 30 & 24 & 50 & 284 \\
\hline Rumah Sawing & K3 & 60 & 150 & Nil & ND & 500 & Nil & Nil & 710 & 130 & 70 & 70 & Firewood & 22 & 292 \\
\hline Rumah Sageng & K5 & 120 & Nil & Nil & ND & Nil & Nil & Nil & 120 & 100 & 10 & 15 & 24 & 30 & 179 \\
\hline Rumah Minsut & $\mathrm{K} 7$ & 50 & Nil & Nil & ND & Nil & Nil & Nil & 50 & 200 & 0 & 10 & 24 & 20 & 254 \\
\hline Rumah Daud & K9 & 50 & 108 & Nil & ND & 540 & Nil & Nil & 698 & 200 & 20 & 40 & 28 & 50 & 338 \\
\hline Average & & 74 & 119 & $\mathrm{Nil}$ & ND & 413 & Nil & Nil & 394 & 156 & 25 & 34 & 25 & 34 & 269 \\
\hline
\end{tabular}

Nil : No income from the product (the data were omitted from the calculation of averages).

ND: no data available.

of pepper peaked in 1998 when that of black pepper shot up to RM 18 per $\mathrm{kg}$. At that time those who had a one-acre pepper garden could easily earn more than RM 3,000 per harvesting season. However, the price of pepper in 2004 has gone down to about RM 3.0 to 4.2 per $\mathrm{kg}$ at Lubok Antu and this has seriously affected the income of the Iban farmers in Lubok Antu, as well as those in Lanjak. The present average income per month from the sale of pepper is RM 220 in Lubok Antu and RM 74 in Lanjak (Tables 5 and 6). Some farmers in Lubok Antu have given up growing pepper, because of the high inputs of fertilizers and agrochemicals needed for its production, even though the price of pepper is low.

Rubber (Hevea brasiliensis) is the second most important cash crop planted by the Iban people, both in Lubok Antu and in Lanjak. Rubber planting was first introduced into Lubok Antu in the late 1930s and in Lanjak around 1940. According to the village heads interviewed, almost all the families in the study areas have rubber gardens and selected interviewed families hold an average area of 4.6 ha in Lubok Antu and 0.65 ha in Lanjak. Although a number of rubber gardens have been left unused for years, mainly because of a lack of manpower and unsatisfactory market prices, many families have resumed tapping to take advantage of the recent rise in the market price of rubber. The price of rubber improved in 2004 to about RM 2.9 to 3.5 per $\mathrm{kg}$ in Lubok Antu. According to the families producing rubber sheets in Lubok Antu, the average monthly income from rubber per family is RM 440 (Table 5). In Lanjak, however, the price of rubber is still low (RM 1.1 per $\mathrm{kg}$ ). This has urged some of the Iban families from Lanjak to sell their rubber, pepper and other agricultural products in the border town of Lubok Antu, where the goods can be sold at a comparatively better price. In Lanjak the average income from the sale of rubber is approximately RM 120 per month (Table 6).

Cocoa (Theobroma cacao) is also planted on a small scale in Lubok Antu, but not in Lanjak. However, most Iban farmers have abandoned their cocoa gardens, because of low price of cocoa and the occurrence of disease. Some farmers are also converting their unproductive cocoa plots into rubber gardens.

The Sarawak Land Consolidation and Rehabilitation Authority (SALCRA) introduced oil palm (Elaeis guineensis) in Lubok Antu in the 1980s as part of the Batang Ai Resettlement Scheme and to develop Native Customary Rights land for large-scale land development programs. A number of the local people who live adjacent to oil palm plantations are engaged in contract work as casual workers. Across the border at Lanjak, no oil palm plantation has been established yet.

The local people plant vegetables adjacent to their longhouses. Eight of 14 families in Lubok Antu gain a petty amount from the sale of vegetables, while people in Lanjak plant vegetables mainly for their own consumption rather than for sale ${ }^{6}$.

\section{Fishing}

As Lanjak is within easy reach of a huge inland lake, Danau, fishing is a profitable venture, particularly for the Iban whose longhouses are near the lake or along the Kapuas River and its tributaries. However, out of the five longhouses surveyed, only people in one, Rumah Sawing, are actively involved in fishing. The average catch is about $50 \mathrm{~kg}$ per month per family with estimated earnings of about RM 150 per month. The four species of fish that are commonly caught are: Tapah (Wallago leeri), Toman (Channa micropeltes), Belida (Notopterus) and Baong (Mystus). Fish are usually sold to 
Chinese merchants who come from the downriver city of Pontianak using trading vessels along the Kapuas River.

Fishing is also seasonal in nature and the income from fishing fluctuates depending on the fish-breeding season. The local people complain that some outsiders, particularly people from Lanjak, have encroached onto their fishing grounds since 2000 and have begun to use poison to catch fish. The locals do not agree with or accept this fishing technique, as it not only kills the fish and reduces the catch, but also pollutes their source of drinking water.

\section{Economic status}

A comparative study of the economic status of the Iban at Lubok Antu and those at Lanjak was conducted based on the data collected during the interviews (Tables 5 and 6$)^{7}$. A detailed analysis of the current economic situation of these two groups reveals that there are stark economic disparities between them. In Lubok Antu for instance, the estimated monthly income per family is about RM 1,245 (Table 5). The income of the Iban in Lanjak is considerably lower (RM 394 per month).

The Iban in Lubok Antu have a wider diversity of income sources than those in Lanjak. For example, cash is obtained from selling pepper, rubber, vegetables and/or oil palm, or from contract wage-labor in urban centres and permanent jobs in the government and private sectors. The Iban in Lanjak have a narrower economic base than those in Sarawak. It is true that the differences in market prices of agricultural products between the two areas have encouraged people in Lanjak to be involved in the economy of Lubok Antu, but the geographical distance and political difference put them at a disadvantage. Some cannot afford to pay for transport to Lubok Antu. In addition, the road is sometimes impassable because of submergence or landslides during the rainy season. The international border is also closed several times a year when the authorities carry out boundary patrols.

Some Iban in Lanjak earn cash from timber-related businesses that do not exist in Lubok Antu at present. A large portion of the income of the Iban in Lanjak derives from selling hand-sawn timber that is cut from nearby forest areas and sold to buyers in Nanga Badau or across the border in Lubok Antu. Some are employed in timber companies as logging supervisors and truck drivers, and some gain royalty from the companies. Many people are eager for this kind of opportunity.

According to the village heads interviewed in Lanjak, besides those engaged in wage work in Indonesia, 10 people from Rumah Dayong, five from Rumah Sawing, five from Rumah Daud and a few from Rumah Minsut are now working mostly in the informal sector in Sarawak, and a few others are employed in Brunei. However, job opportunities for Indonesian Iban are much more limited compared to those for Sarawak residents due to their lack of Malaysian ${ }^{8}$ citizenship. Some people worry that stricter control of the movement of people across the border to Sarawak and Brunei will be established in future; this would restrict their chances of getting jobs in Sarawak or Brunei.

The Iban in Lanjak spend about RM 269 a month per family, $58.0 \%$ of this being spent on food. For the Iban in Lubok Antu, the average expenditure is about RM 527 per month per family, which is equivalent to about $37.2 \%$ of their total income. About $63.0 \%$ of their total expenditure is spent on food.

Some seasonal and occasional expenditures, such as the purchase of chemical fertilizers and agrochemicals, transportation fees, funds spent on ritual festivals and celebrations etc., are not included in Tables 5 and 6 . If these extra expenses are considered, it can be said that the cost of living for the Iban in Lubok Antu is about twice as much as for those in Lanjak. When earnings and expenses are compared, it is clear that the Iban in Lubok Antu have a relatively larger disposable income.

It was also noted that the Iban in Lanjak tend to purchase their essential goods from the border town of Lubok Antu in Sarawak, because it is nearer to their longhouses and has better facilities and a wider choice of goods compared to Indonesian towns such as Lanjak and Nanga Badau. This generates more economic activities for Lubok Antu, leaving the Indonesian side at a disadvantage.

\section{CONCLUSION}

From this study it is evident that there are both similarities and differences between the agricultural practices of the Iban in Lubok Antu, Sarawak and the Iban in Lanjak, Ulu Kapuas, Kecamatan Batang Lupar in West Kalimantan. Both groups of Iban still practice traditional shifting cultivation and continue to observe the rites and customs to some extent, but the fallow period in Lubok Antu is often shortened, compared to the five to eight year fallow period in Lanjak. This 
may be partly due to the shortage of forested land in Lubok Antu. It was also observed that rice production in Lubok Antu is lower than in Lanjak. The Iban farmers in Lubok Antu tend to clear a comparatively bigger area for farming, use a considerable amount of fertilizers and other agrochemicals, prefer to use the same land near the longhouse repeatedly and have also developed rice cultivation in lowland swamps to compensate for the low rice yield. Moreover, according to the residents, these agricultural changes are also intended to save labor, which enables some family members (usually males) to engage in wage-earning jobs outside the village to supplement their income.

The differences between the two areas in terms of the acreage planted with rice, yield and application of fertilizers and other agrochemicals may partly be due to the intensification of agricultural practices and the decline in soil fertility. However, the different political systems in the region have a large effect on the divergence of agricultural methods between the two groups of Iban. For example, while the Sarawak Government more frequently (sometimes excessively) provide agricultural subsidies or economic and technical assistance (e.g. the introduction of new cash crops and the distribution of fertilizers and agrochemicals), the Indonesian Government is relatively reluctant to increase subsidies or assistance to remote areas such as Lanjak.

The economic disparity and the gap in market prices between the two areas also affect the activities of the Iban in the areas researched. Those who live in Lanjak frequently go across the border to Lubok Antu to buy agricultural and other consumer goods and to sell agricultural products. Many also enter the labor market in Sarawak for a supplementary cash income. In other words, they have been involved to a large extent in the economy of Sarawak.

Thus, cultural homogeneity, economic integrity, and political or institutional divides are intricately tangled in the way that they affect the subsistence, including the agricultural practices, of the Iban groups studied. This study began as an investigation of the similarity and differences in agricultural activities between two Iban groups at the periphery of the border area and brought to light various socio-economic differences between the groups that require further investigation.

ACKNOWLEDGEMENTS This study was supported by a Grant-in-Aid for Scientific Research from the Japan Society for the Promotion of Science (No.13575038 and No.15720195) and a grant from the Toyota Foundation. We also wish to thank the Director of Forests, Sarawak and staff of the Forest Department, Sarawak for assistance rendered during this study.

\section{REFERENCES}

Austin, R. F. 1977. Iban Migration: Patterns of Mobility and Employment in the 20th Century. U. M. I. Dissertation Information Service, A Bell \& Howell Infor. Co., 3-4. Michigan.

Best, J. R. 1988. Change over time in a farming system based on shifting cultivation of hill rice in Sarawak, Malaysia. Agricultural Administration and Extension 29: 69-84.

Brooke, C. 1866. Ten Years in Sarawak. Tinsley Brothers, London. 334 pp.

Christensen, H. \& Mertz O. 1993. The risk avoidance strategy of traditional shifting cultivation in Borneo. Sarawak Museum Journal 46: 2-18.

Cramb, R. A. 1985. The importance of secondary crops in Iban hill rice farming. Sarawak Museum Journal 34: $37-45$.

Cramb, R. A. 1989. The use and productivity of labor in shifting cultivation: An east Malaysian case study. Agricultural Systems 29: 97-115.

Freeman, J. D. 1955. Iban Agriculture: A Report of the Shifting Cultivation of Hill Rice by the Iban of Sarawak. 148 pp., H. M. Stationery Office, London.

Freeman, D. 1970. Report of the Iban. Pp. 140-142, The Athlone Press, University of London, London.

Hatch, T. \& Lim C. P. 1978. Shifting Cultivation in Sarawak. 28 pp., Soil Division, Department of Agriculture, Sarawak, Kuching.

Ichikawa, M. 2000. Transformation of shifting swamp-rice cultivation in an Iban village of Sarawak, Malaysia. Southeast Asian Studies 38: 226-248.

Ichikawa, M. 2004. Relationship among secondary forests and resource use and agriculture, as practiced by the Iban of Sarawak, East Malaysia. Tropics 13: 269-286

Jensen E. 1965. Hill rice. An introduction to the hill padi cult of the Sarawak Iban. Folk Dansk Ethnografisk Tidsskrift 7: 43 
$-88$.

Kedit, P. M. 1993. Iban Bejalai. Sarawak Literary Society, Kuching. 202 pp.

Kendawang, J. J., Tanaka, S., Ishihara, J., Shibata, K., Sabang, J., Ninomiya, I., Ishizuka S. \& Sakurai, K. 2004. Effects of shifting cultivation on soil ecosystems in Sarawak, Malaysia. I. Slash and burning at Balai Ringin and Sabal experimental sites and effect on soil organic matter. Soil Science and Plant Nutrition 50: 677-687.

King, V. T. 1976. Migration, Welfare and Culture Contact in Borneo: A Critique of Ecological Analysis. Oceania 46: 306327.

Lawrence, D., Peart, D. R. \& Leighton, M. 1998. The impact of shifting cultivation on a rainforest landscape in West Kalimantan: spatial and temporal dynamics. Landscape Ecology 13: 135-148.

Padoch, C. 1982. Migration and its Alternatives among the Iban of Sarawak. Koninklijk Instituut voor Tall-, Land- en Volkenkunde, Leiden. $126 \mathrm{pp}$.

Padoch, C., Harwell, E. \& Susanto, A. 1998. Swidden, sawah, and in-between: agricultural transformation in Borneo. Human Ecology 26: 3-20.

Pringle, R. 1970. Rajahs and Rebels: The Ibans of Sarawak under Brooke Rule, 1841-1941. 410 pp., Macmillan, London.

Sandin, B. 1957. The Sea Dayak migration to Niah river. Sarawak Museum Journal 8: 133-135.

Sandin, B. 1967a. The westward migration of the Sea Dayaks. Sarawak Museum Journal 7: 54-81.

Sandin, B. 1967b. The Sea Dayaks of Borneo before the White Rajah Rule. East Lansing. Macmillan, London.

Sandin, B. 1967c. Peturun Iban. Borneo Literature Bureau, Kuching. 134 pp.

Soda, R. 2005. Changing family relations among the Iban: the presence of city dwellers and their rights to rural property. Sarawak Development Journal (in printing).

Szott, L. T., Palm, C. A. and Buresh, R. J. 1999. Ecosystem fertility and fallow function in the humid and subhumid tropics. Agroforestry Systems 47: 163-196

Tanaka, S., Kendawang, J. J., Ishihara, J., Shibata, K., Kou, A., Jee, A., Ninomiya, I. \& Sakurai, K. 2004. The effects of shifting cultivation on soil ecosystems in Sarawak, Malaysia. II. Changes in soil chemical properties and runoff water at Balai Ringin and Sabal Experimental sites. Soil Science and Plant Nutrition 50: 689-699.

Tun Jugah Foundation 2001. Iban Communities in West Kalimantan. In The Encyclopedia of Iban Studies. Vol. 2, Pp. 716734, The Tun Jugah Foundation, Kuching.

Wadley, R. L. 1997. Circular labor migration and subsistence agriculture: A case of the Iban in West Kalimantan, Indonesia. Unpublished Ph.D. dissertation. Arizona State University.

Wadley, R. L. 1998. The road to change in the Kapuas Hulu borderlands: Jalan Lintas Utara. Borneo Research Bulletin 29: 71-94.

\section{NOTES}

1 The longhouse is a community comprising of a number of families living together. Longhouses are found widely in Sarawak, while in Indonesia such settlement patterns are found only in the remotest areas. The interior of the longhouse is mainly composed of bilek (separate family rooms) and a ruai (common corridor). The bilek is the smallest spatial unit in which a stem family is supposed to live. This family unit seems to coincide with the term 'household' in the sense that it forms a management unit for shifting cultivation and is rather autonomous, both socially and economically. However, the concept of 'household' in Iban studies has definitional problems (see Wadley 1997). To avoid controversy, this paper calls such unit the bilek-family, following previous Iban studies. For the remainder of this paper, when we use the term, 'family' and 'village', the former refers to the bilek-family and the latter to the longhouse community.

2 According to Wadley (1998), the population of the four kecamatan is approximately 20,000-25,000 with a density of about three people per square $\mathrm{km}$, the Iban making up the largest block at about 50 to $60 \%$ of the total population.

3 Surveyed longhouses in Lubok Antu were chosen as typical ones in the area at the suggestion of staff members of the Forest Department, Sarawak, who were the Iban. All longhouses in the area are accessible by feeder roads. As for longhouses in Lanjak, we were given advice and assistance by a local Iban political leader in selecting five longhouses. The selected longhouses include the three longhouses along the paved Northern Road (two of them are located on flat lowland and one on a slightly elevated hill), one longhouse situated a few hundred meters inland away the main 
Northern Land (accessible by land cruiser), and one longhouse which can be reached only by boat across the lake. In deciding the interviewees, we asked the heads of longhouses to introduce us to people who have relatively accurate and adequate knowledge of rice farming practices. Thus, although the number of data collected may not be sufficient, according to our general observation in the fields, the data are considered to accurately represent the rice farming conditions and other economic activities in the study areas.

$4 \mathrm{RM}$ is the abbreviation for Ringgit Malaysia (Malaysian currency). This currency also circulates in the border areas of Indonesia. In this paper we use this unit of currency to indicate economic statuses both in Malaysia and Indonesia. The exchange rate for RM has been fixed at US \$1.00 to RM 3.80 since September 1998.

5 Although it is difficult to estimate the livelihood of the Iban in rural areas because of seasonal and yearly fluctuations, we asked the respondents to answer the approximate monthly average in the previous year (2003), giving careful consideration to the seasonality of income from cash crops, temporal contract wage-jobs, occasional expenditures for children at the beginning of a new school year, unexpected expenditures in cases of sickness, etc..

6 Some respondents replied that they sometimes sell vegetables to logging workers, but that the income is too small to be calculated.

7 As for the number of bilek-family members, it is very difficult to decide whether to include those who engage in wagework away from villages as family members (Soda, forthcoming). Most of respondents in Lubok Antu alleged that adult children working outside villages should be considered family members, because they frequently go back and forth between the longhouse and the city, and not only remit money to the parents in longhouses, but also bring rice back to the city for self-consumption. In Lanjak, since the major destinations of labor migrations are the cities in Sarawak, the period of absence of wage-workers is much longer, and therefore, the respondents in Lanjak tend to exclude such family members as being counted as current residents of the bilek. These tendencies may affect the difference in the average number of family members in the two areas (cf. Tables 1 and 2).

8 Some Indonesian respondents obtained Malaysian identity cards while working in Sarawak in the 1970s and 1980s. Nowadays it is difficult for them to gain Malaysian citizenship due to the more stringent employment and immigration policies in Sarawak, and Malaysia as a whole.

Received $14^{\text {th }}$ Jan. 2005

Accepted 23 $3^{\text {rd }}$ June 2005 